\title{
Exopolysaccharide (EPS) Producing Isolates from Sugarcane Field Soil and Antibacterial Activity of Extracted EPSs
}

\section{Kruti K Patel, Firdosh Shah and Mitesh Dwivedi*}

C. G. Bhakta Institute of Biotechnology, Faculty of Science, Uka Tarsadia University, Gujarat, India

*Corresponding Author: Mitesh Dwivedi, C. G. Bhakta Institute of Biotechnology, Faculty of Science, Uka Tarsadia University, Gujarat, India.

Received: January 30, 2018; Published: March 07, 2018

DOI: $10.31080 /$ ASMI.2018.01.0032

\begin{abstract}
Microbial exopolysaccharides (EPSs) are reported to possess unique physiological activities including anti-microbial, anti-tumor, and anti-inflammatory. The antimicrobial activities of EPS could be used as a potential source for the development of antimicrobial drugs and may have various industrial, pharmaceutical and medical applications. The present study was aimed to isolate efficient EPS producing bacteria from sugarcane field soil and to evaluate the antibacterial activity of EPSs. Total 9 EPS producing isolates were obtained out of which, KPEP3 and KPEP4 were found to be higher producers of EPS. The isolates were able to grow at different $\mathrm{pH}$ but EPS production was higher at $\mathrm{pH}$ 6. The maximum carbohydrate content was found in KPEP3 and minimum protein content was found in KPEP4 suggestive of their probable use in medicine due to less immunogenicity. The evaluation of antibacterial activity of EPS suggested that all 4 test microorganisms (E. coli, B. cereus, B. subtilis and V. cholerae) showed sensitivity against EPSs but the sensitivity varied from one microorganism to another. The KPEP3 and KPEP4 EPSs were found to exert higher antibacterial activity on diverse test organisms. EPSs concentration of $7.5 \mathrm{mg} / \mathrm{ml}$ was found to be effective for antibacterial activity. The MIC values of EPSs suggested that they can be used at lower concentration to inhibit test organisms. The biochemical characterization indicated that these isolates may belong to genera: Bacillus and Pseudomonas. Further research is necessary to elucidate the composition and efficacy of the EPSs by using in vitro and in vivo animal model studies.
\end{abstract}

Keywords: Exopolysaccharides (EPSs); Bacterial EPS; Antibacterial Activity

\section{Abbreviations}

EPSs: Exopolysaccharides; MIC: Minimum Inhibitory Concentration

\section{Introduction}

Exopolysaccharides (EPSs) are high molecular-weight polymers that are composed of sugar residues [1]. Microorganisms synthesize a wide spectrum of multifunctional polysaccharides including intracellular polysaccharide, structural polysaccharide and extracellular polysaccharide. The bacterial exopolysaccharides are secreted by microorganisms into the surrounding environment and are synthesized in two basic forms of capsular EPS and slime EPS [2]. Bacteria produce diverse biopolymers with varied chemical properties via utilization of simple to complex substrates. The maximal EPS production occurs generally at the end of the growth phase. In both natural conditions and laboratory microorganisms tend to produce more EPS under nitrogen limiting conditions. However, the ability to produce EPSs is widely spread among bacteria. The EPSs generally consist of monosaccharides and some non-carbohydrate substituents such as protein, nucleic acids, lipids, acetate, pyruvate, succinate, and phosphate.
Microbial EPS plays an important task in interaction between bacteria and their environment. A bacterial cell surrounded by EPS is protected from such environmental insults as extreme dry conditions, predation, and antibiotics effects. Bacterial exopolysaccharide likely contribute to such processes as microbial aggregation, surface attachment, biofilms formation, plant-microbe symbiosis, and environmental bioremediation. Earlier, bacterial EPSs obtained from Pseudomonas aeruginosa, Sphingomonas paucimobilis, Streptococcus thermophilus, Bacillus subtilis have achieved great success. Some of these EPSs serve the same function whereas others are specific for certain taxa and serve distinct biological functions [3]. The EPSs may possess unique physiological activities such as antimicrobial, anti-tumor and anti-inflammatory, as well as can act as an inducer for interferon, platelet aggregation inhibition and colony stimulating factor synthesis. These polysaccharides are non-toxic and biodegradable and can be used as active ingredient in pharmaceutical products, cosmetics and as raw material for industrial use such as thickeners, stabilizers, emulsifiers, gelling agents and water binding agents in food etc $[4,5]$. The direct application of the biological properties of exopolysaccharide towards 
medicine includes: the exopolysaccharides as vaccines in preference to whole microbial cells or their cultures. Thus side-effects because of other cell components such as lipo-polysaccharides or proteins can be avoided. Advances in the application of bacterial exopolysaccharides in medicine and biotechnology have seen uses to include bacterial alginate in cell microencapsulation, such as microsphere vectors for drug delivery, making dental impressions, as an active ingredient in absorbent dressings, and anti-reflux therapies [6]. Currently, emergence of drug resistant bacterial strains has put forward an immediate need for other alternates of antibiotics which can be efficient in controlling the infectious conditions caused by these strains. EPSs from such bacteria can serve as better and may be the novel source to combat with such infections. Therefore, the present study was aimed to isolate efficient EPS producing bacteria from sugarcane field soil sample, to extract the EPS and to evaluate the antibacterial activity of the EPS.

\section{Materials and Methods}

\section{Collection of Samples}

Soil samples were collected from two different sugarcane fields of South Gujarat region (India). The samples were collected from upper layer of the farmland where maximum population of microorganisms was concentrated. $5 \mathrm{~g}$ of soil sample was collected in sterile plastic bags and carried to the laboratory.

Isolation and purification of exopolysaccharide producing bacteria

For reducing microbial population, $1 \mathrm{~g}$ of soil was dissolved in 10 $\mathrm{ml}$ of sterile distilled water to make soil suspension. Isolates were obtained by serial dilution plating on nutrient agar medium. $0.1 \mathrm{ml}$ of each dilution $\left(10^{-1}\right.$ to $\left.10^{-5}\right)$ of soil suspension was poured on nutrient agar plates. After incubation for $24 \mathrm{hrs}$ at $37^{\circ} \mathrm{C}$, mucous colonies were observed on the plates. Isolates were maintained on nutrient agar plates. Mucoid colonies were screened and re-streaked on another nutrient agar plate to obtain pure culture. The Bacterial isolates were maintained on Nutrient agar slant and stored in refrigerator.

Phenotypic and Biochemical characterization of the EPSproducing Bacteria

Isolated cultures were identified on the basis of morphological, biochemical and microscopic observations. The identification work was done according to the methods described in Bergey's Manual of determinative bacteriology $9^{\text {th }}$ edition.

\section{Exopolysaccharide Production}

Isolated organisms were used for production of exopolysaccharides. Production was carried out in $250 \mathrm{ml}$ flasks containing 50 $\mathrm{ml}$ of medium [7]. The medium consisting of the following components (g/l): peptone $10 \mathrm{gm}$, meat extracts $3 \mathrm{gm}$, sodium chloride 5 gm and sucrose $2 \%$. Media was sterilized at $1210 \mathrm{C}$ for 20 minutes. The $\mathrm{pH}$ of media was adjusted to 6.5. The flasks were incubated on a rotary shaker at room temperature for $72 \mathrm{hrs}$.

\section{Isolation and Extraction of EPS}

The cells were harvested by centrifugation for 20 minutes at $10,000 \mathrm{rpm}$. After centrifugation, two volumes of ice cold isopropanol were added into it and stored overnight at 40C. Precipitated material was collected by centrifugation (20 minutes at 10,000 $\mathrm{rpm}$ ) and the pellets were dried at 1000C. After drying, the pellet was weighed to know which organism showed higher production of exopolysaccharides. The isolates were also checked for their ability to grow and produce EPS at different $\mathrm{pH}(6.0,7.0,8.0$ and 9.0).

Estimation of Carbohydrate and Protein content of crude EPS

The total carbohydrate content was estimated by Anthrone's method. The principle includes carbohydrates are hydrolyzed by treating with acid to form furfurals and hydroxy-methyl furfural. These furfural are then condensed by enthrone reagent to form a blue green color complex. The intensity of which can easily be measured with 620 - $630 \mathrm{~nm}$ using photo colorimeter or spectrophotometer. This absorbance can then be used to calculation the amount of carbohydrates using beer- lamberts law $[8,9]$. The amount of protein present in the EPS was estimated by the folinphenol reagent [10].

\section{Qualitative tests for carbohydrates}

Monosaccharide, oligosaccharide and polysaccharide were detected by Molisch test, Fehling's test, Benedicts test and Barfoed test respectively [11].

Determination of antibacterial activity and minimum inhibitory concentration (MIC) of EPS

\section{Antibacterial activity of EPS}

Antibacterial activities were achieved by using disk diffusion method and quantifying the clear zone of inhibition around the filter paper disk. In this method, the autoclaved filter paper discs were impregnated with $50 \mu \mathrm{l}$ of the undiluted EPSs $(2.5 \mathrm{mg} / \mathrm{ml}$, $5 \mathrm{mg} / \mathrm{ml}$ and $7.5 \mathrm{mg} / \mathrm{ml}$ ) and positioned on nutrient agar plates seeded with the test organisms. Two gram positive organisms: Bacillus subtilis and Bacillus cereus and two gram negative organisms: Escherichia coli and Vibrio cholerae were used in this study. The distilled water soaked in paper disk was used as a negative control. The antibiotic Gentamycin was used as positive control. After firm placement of the discs the plates were incubated at $37^{\circ} \mathrm{C}$ in inverted position for 1 - 2 days to allow different species of bacteria to grow. The zones of inhibition in discs were measured by millimeter scale [12]. 


\section{Determination of MIC of EPS}

Minimum inhibitory concentration (MIC) of EPS was performed by macro-dilution method. The crude EPS extract was dissolved in distilled water. Bacterial suspension of the test organisms were prepared in sterilized Mueller-Hinton broth. Then $1 \mathrm{ml}$ of the dilution was added to each sterilized screw cap tube containing $1 \mathrm{ml}$ of compound suitably diluted in the sterilized broth medium to make final volume of $2 \mathrm{ml}$. Culture medium without sample and other without micro-organism were used in test as control. Tubes were incubated at 370C for 24 hours. Later they were analyzed by spectrophotometer at $600 \mathrm{~nm}$.

\section{Results and Discussion}

Two soil samples were collected from sugarcane fields of South Gujarat region for this study. The samples were serially diluted and plated for screening of efficient EPS producing microorganisms. After $24 \mathrm{hrs}$ of incubation at $37 \mathrm{oC}$ the nutrient plates exhibited numerous bacterial colonies. Out of which mucoid colonies were screened and transferred on to nutrient agar plate to obtain pure culture. Total 9 ( 5 from soil sample 1 and 4 from soil sample 2 ) mucoid colonies were obtained which were designated as exopolysaccharide producing isolates (Figure 1). The isolates obtained from soil sample 2 (KPEP1 to KPEP4) were found to be more potent EPS producers as compared to soil sample 1 (KT1 to KT5) isolates and hence they were further considered.
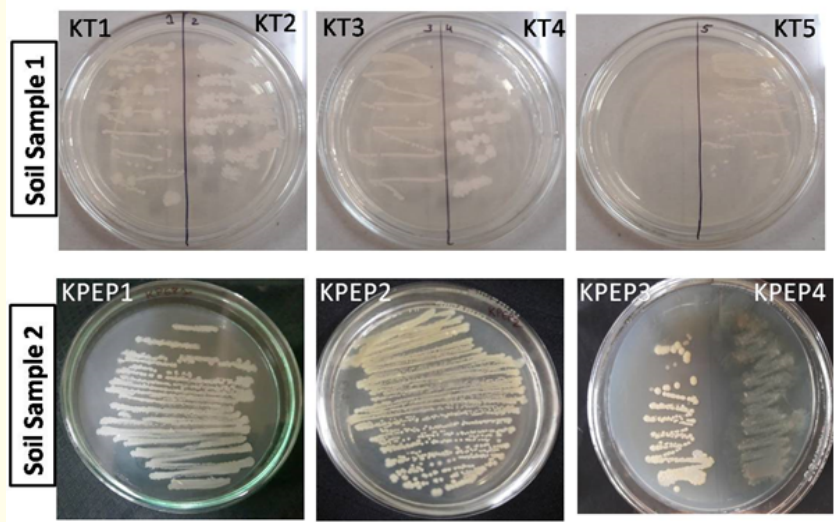

Figure 1: Isolation of EPS producing bacteria: Bacterial Colonies were isolated from different dilutions of soil samples. Numerous colonies were obtained out of which total 9 mucoid isolated colonies ( 5 from soil sample 1 and 4 from soil sample 2) were selected from higher dilution plates and designated as exopolysaccharide producing isolates.

\section{Effect of pH on EPS production}

Since, the change in $\mathrm{pH}$ affects the production of EPS, the bacterial isolates (KPEP1 to KPEP4) were streaked on media containing different $\mathrm{pH}(6.0,7.0,8.0$ and 9.0). The organisms were able to grow at different $\mathrm{pH}$ but the bacterial growth and EPS production

was observed higher at $\mathrm{pH} 6$ as compared to other $\mathrm{pH}$ (Figure 2) The $\mathrm{pH} 6.0$ was considered further for growth of bacteria in broth media and extraction of EPS.

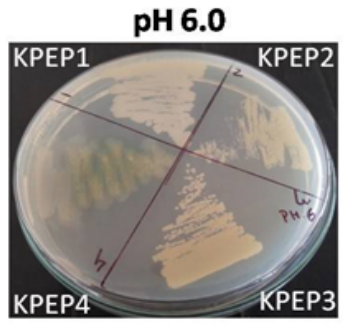

pH 8.0

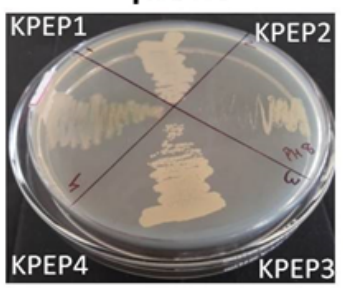

Figure 2: EPS producing bacterial isolates at different $\mathrm{pH}$ (6.0, 7.0, 8.0 and 9.0): The bacterial isolates' growth was found to be optimum at pH 6.0 along with the good EPS production.

\section{Extraction of EPS from EPS producing bacteria}

Out of the total 9 isolates, 4 isolates were used for EPS production and extraction. The EPS from all four isolates were successfully extracted in the dried form and weighed. Among them KPEP3 and KPEP4 were found to be higher producers of EPS with $0.259 \mathrm{~g}$ and $0.312 \mathrm{~g}$ EPS production respectively from $100 \mathrm{ml}$ culture broth (Figure 3).

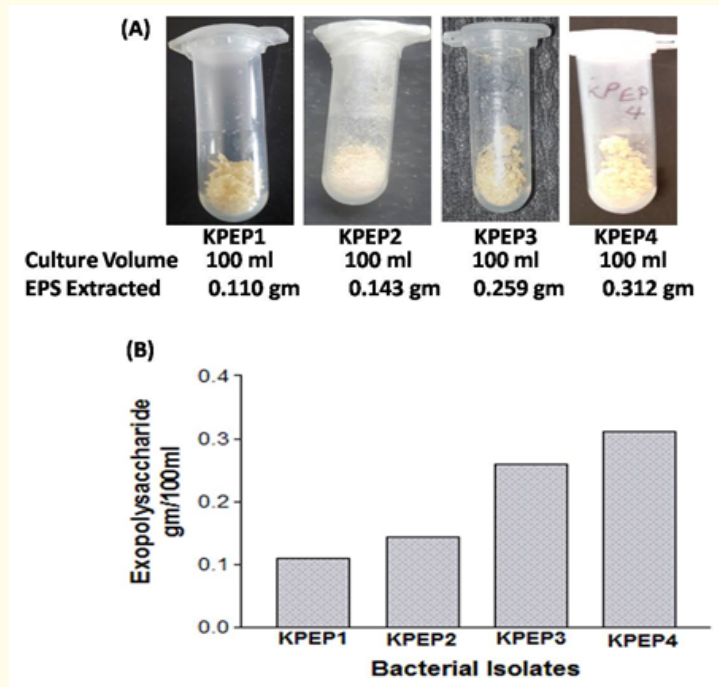

Figure 3: Exopolysaccharide production by bacterial isolates: (A) Representative dried EPS in eppendorf tubes obtained from $100 \mathrm{ml}$ culture broth of 4 bacterial isolates. (B) The EPS production was found higher in KPEP4 followed by KPEP3, KPEP2 and KPEP1. 
Estimation of Carbohydrate and Protein content of crude EPS

The Dried EPS was used for estimation of total carbohydrate and protein content. The carbohydrate content was estimated by Anthrone's method and the total protein content of EPS was measured by Folin-Lowry method. All four isolates EPS showed good amount of carbohydrate (Figure 4). The maximum carbohydrate content was found in KPEP3 $(0.72 \mathrm{mg} / \mathrm{ml})$ and minimum was found in KPEP2 $(0.58 \mathrm{mg} / \mathrm{ml})$. However, the protein content of the isolates' EPS was found to be lowered as compared to carbohydrate. The higher protein content was found in KPEP1 $0.065 \mathrm{mg} /$ $\mathrm{ml}$ ) and lower protein content was found in KPEP4 $(0.010 \mathrm{mg} / \mathrm{ml})$. Due to higher immunogenicity of proteins, it is desirable to have less protein content in the microbial products which are used for medicinal purposes.

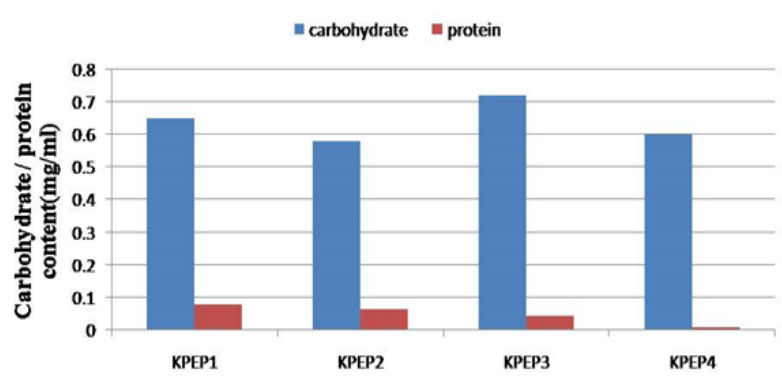

Figure 4: Carbohydrate and protein content of EPS: The EPS of KPEP3 showed maximum carbohydrate content $(0.72 \mathrm{mg} / \mathrm{ml})$ as compared to EPS from other 3 isolates. The minimum carbohydrate content was found in EPS of KPEP2 $(0.58 \mathrm{mg} / \mathrm{ml})$. The protein content was found to be minimum in KPEP4 $0.010 \mathrm{mg} /$ $\mathrm{ml})$ and maximum in KPEP $1(0.065 \mathrm{mg} / \mathrm{ml})$.

\section{Qualitative tests for carbohydrates}

Monosaccharide, oligosaccharide and polysaccharide were detected by Molisch test, Fehling's test, Benedicts test and Barfoed test respectively (Table 1). The sugar content in EPS was reducing sugar in most of the extracted EPS, except in KPEP4 EPS which contained non-reducing sugar. In barfoed's test the red color precipitation indicates the presence of reducing monosaccharide and EPS of KPEP2 and KPEP3 showed positive result. In Bial's test formation of blue-green color indicates presence of pentose sugar and only KPEP1-EPS showed positive bial's test which indicates the presence of pentose sugar like Arabinose and Xylose. Seliwanoff's test is positive when cherry red color is observed. All the EPS showed negative results for Seliwanoff's test which indicates the absence of ketohexoses in EPS. Mucic acid test is used for identification of galactose or glucose containing sugars. The observation of crystals under low power of microscope indicates positive test and KPEP3 showed positive results for Mucic acid test. Phenylhydrazine test is indicated positive on the basis of crystal formed and their shape and time take to form crystals. No crystal formation was observed for all EPS which indicates negative result and suggesting for the presence of mannose.

\begin{tabular}{|c|c|c|c|c|}
\hline Test & KPEP1-EPS & $\begin{array}{l}\text { KPEP2- } \\
\text { EPS }\end{array}$ & $\begin{array}{l}\text { KPEP3- } \\
\text { EPS }\end{array}$ & $\begin{array}{l}\text { KPEP4- } \\
\text { EPS }\end{array}$ \\
\hline $\begin{array}{l}\text { Molisch } \\
\text { test }\end{array}$ & $\begin{array}{c}\text { Positive } \\
\text { (Red-violet layer) }\end{array}$ & Positive & Positive & Positive \\
\hline $\begin{array}{l}\text { Fehling's } \\
\text { test }\end{array}$ & $\begin{array}{l}\text { Positive (Green } \\
\text { suspension and } \\
\text { red precipitate) }\end{array}$ & Positive & Positive & $\begin{array}{l}\text { Nega- } \\
\text { tive }\end{array}$ \\
\hline $\begin{array}{l}\text { Bene- } \\
\text { dict's test }\end{array}$ & $\begin{array}{l}\text { Positive (Yellow } \\
\text { color precipitate } \\
\text { observed) }\end{array}$ & Positive & Positive & $\begin{array}{l}\text { Nega- } \\
\text { tive }\end{array}$ \\
\hline $\begin{array}{l}\text { Barfoed's } \\
\text { test }\end{array}$ & $\begin{array}{l}\text { Negative (No } \\
\text { red precipitate } \\
\text { observed) }\end{array}$ & Positive & Positive & $\begin{array}{l}\text { Nega- } \\
\text { tive }\end{array}$ \\
\hline Bial's test & $\begin{array}{c}\text { Positive (Greenish } \\
\text { color observed) }\end{array}$ & Negative & $\begin{array}{l}\text { Nega- } \\
\text { tive }\end{array}$ & $\begin{array}{l}\text { Nega- } \\
\text { tive }\end{array}$ \\
\hline $\begin{array}{l}\text { Seliwan- } \\
\text { off's test }\end{array}$ & $\begin{array}{c}\text { Negative } \\
\text { (No color ob- } \\
\text { served) }\end{array}$ & Negative & $\begin{array}{l}\text { Nega- } \\
\text { tive }\end{array}$ & $\begin{array}{l}\text { Nega- } \\
\text { tive }\end{array}$ \\
\hline $\begin{array}{l}\text { Mucic } \\
\text { acid test }\end{array}$ & $\begin{array}{c}\text { Negative (No } \\
\text { Crystals observed) }\end{array}$ & Negative & Positive & $\begin{array}{l}\text { Nega- } \\
\text { tive }\end{array}$ \\
\hline $\begin{array}{l}\text { Phenyl- } \\
\text { hydrazine } \\
\text { test }\end{array}$ & $\begin{array}{c}\text { Negative (No } \\
\text { Crystals observed) }\end{array}$ & Negative & Positive & $\begin{array}{l}\text { Nega- } \\
\text { tive }\end{array}$ \\
\hline $\begin{array}{l}\text { Predicat- } \\
\text { ed sugar }\end{array}$ & Arabinose/Xylose & Glucose & $\begin{array}{l}\text { Galac- } \\
\text { tose }\end{array}$ & Sucrose \\
\hline
\end{tabular}

Table 1: Qualitative tests for carbohydrates present in extracted EPS.

Determination of antibacterial activity and minimum inhibitory concentration (MIC) of EPSs

\section{Antibacterial activity of EPSs}

Antibacterial activities were achieved by using disk diffusion method by quantifying the clear zone of inhibition around the filter paper disk. The autoclaved filter paper discs were impregnated with EPSs and positioned on nutrient agar plates seeded with the test organisms.

The table 2 shows the diameter of zone of inhibition ( $\mathrm{mm}$ ) obtained for each EPS on the growth of different test microorganisms. The EPS concentration $2.5 \mathrm{mg} / \mathrm{ml}$ was found to be very less in order to show the antibacterial activity (Figure 5A). In contrary, at $5 \mathrm{mg} / \mathrm{ml}$ and $7.5 \mathrm{mg} / \mathrm{ml}$ concentration all tested microorganisms showed sensitivity to EPS but their efficiency in inhibition was varied from one microorganism to another (Figure 5B and 5C). The diameter of inhibition zones ranged between 1 and $9 \mathrm{~mm}$. The large zone of inhibition was observed against B. cereus, B. subtilis and $V$. cholerae while the lowest was recorded against the $E$. coli. All four isolates' EPS were found to exert the higher antibacterial activity against $B$. cereus, B. subtilis and $V$. cholerae at EPS concentration of $7.5 \mathrm{mg} / \mathrm{ml}$. These four isolates' EPS (KPEP1 to KPEP4) were shown 
to have inhibitory effect on the growth of $E$. coli at $5 \mathrm{mg} / \mathrm{ml}$ concentration; however, only KPEP1 and KPEP2 were found to affect the growth of B. cereus at $5 \mathrm{mg} / \mathrm{ml}$ concentration. The KPEP3 and KPEP4 were shown to affect the $V$. cholerae at $5 \mathrm{mg} / \mathrm{ml}$ concentration. The B. subtilis were not affected by EPS of KPEP1 and KPEP2; however, KPEP3 and KPEP4 showed moderate inhibition at $5 \mathrm{mg} /$ $\mathrm{ml}$ concentration. Overall, KPEP3 and KPEP4 were found to exhibit higher antibacterial activity on the diverse test organisms. The EPS concentration of $7.5 \mathrm{mg} / \mathrm{ml}$ was found to be effective for antibacterial activity (Figure $5 \mathrm{C}$ ).

\begin{tabular}{|c|c|c|c|c|c|}
\hline \multirow[b]{2}{*}{ Isolate } & \multirow{2}{*}{$\begin{array}{c}\text { EPS } \\
\text { (mg/ } \\
\text { ml) }\end{array}$} & \multicolumn{4}{|c|}{ Diameter of Zone of Inhibition (mm) } \\
\hline & & $\begin{array}{c}\text { Esch- } \\
\text { erichia } \\
\text { coli }\end{array}$ & $\begin{array}{c}\text { Bacillus } \\
\text { subtilis }\end{array}$ & $\begin{array}{c}\text { Bacillus } \\
\text { cereus }\end{array}$ & $\begin{array}{c}\text { Vibrio } \\
\text { cholerae }\end{array}$ \\
\hline \multirow[t]{3}{*}{ KPEP1 } & 2.5 & 1 & 0 & 2 & 0 \\
\hline & 5.0 & 6 & 0 & 9 & 0 \\
\hline & 7.5 & 6 & 2 & 9 & 3 \\
\hline \multirow[t]{3}{*}{ KPEP2 } & 2.5 & 0 & 0 & 0 & 0 \\
\hline & 5.0 & 4 & 0 & 2 & 0 \\
\hline & 7.5 & 4 & 4 & 2 & 3 \\
\hline \multirow[t]{3}{*}{ КРEP3 } & 2.5 & 0 & 0 & 0 & 0 \\
\hline & 5.0 & 3 & 1 & 1 & 2 \\
\hline & 7.5 & 3 & 6 & 1 & 6 \\
\hline \multirow[t]{3}{*}{ KPEP4 } & 2.5 & 0 & 0 & 0 & 4 \\
\hline & 5.0 & 4 & 3 & 0 & 4 \\
\hline & 7.5 & 4 & 9 & 0 & 8 \\
\hline $\begin{array}{l}\text { Genta- } \\
\text { mycin }\end{array}$ & $10 \mu \mathrm{g}$ & 16 & 15 & 12 & 14 \\
\hline
\end{tabular}

Table 2: Antibacterial activity of EPS against test microorganisms.

\section{Minimum inhibitory concentration (MIC) of EPSs}

The MIC values of the EPS samples from KPEP1, KPEP2, KPEP3 and KPEP4 were studied against different test organisms. The data obtained are shown in table 3 . With respect to the ability of different EPSs against test organisms, KPEP4 was found to inhibit the growth of Bacillus subtilis at MIC of $6.8 \mathrm{mg} / \mathrm{ml}$ as compared to other EPSs. The MIC of $7.6 \mathrm{mg} / \mathrm{ml}$ was found to inhibit the growth of Vibrio cholerae by KPEP 2. However, EPSs of KPEP1 and KPEP3 were found to inhibit the growth of $E$. coli and Bacillus cereus at the MIC values of 8.7 and $9.4 \mathrm{mg} / \mathrm{ml}$ respectively. This suggests that the EPSs from all the four bacterial isolates would easily inhibit microbial growth at low concentrations.

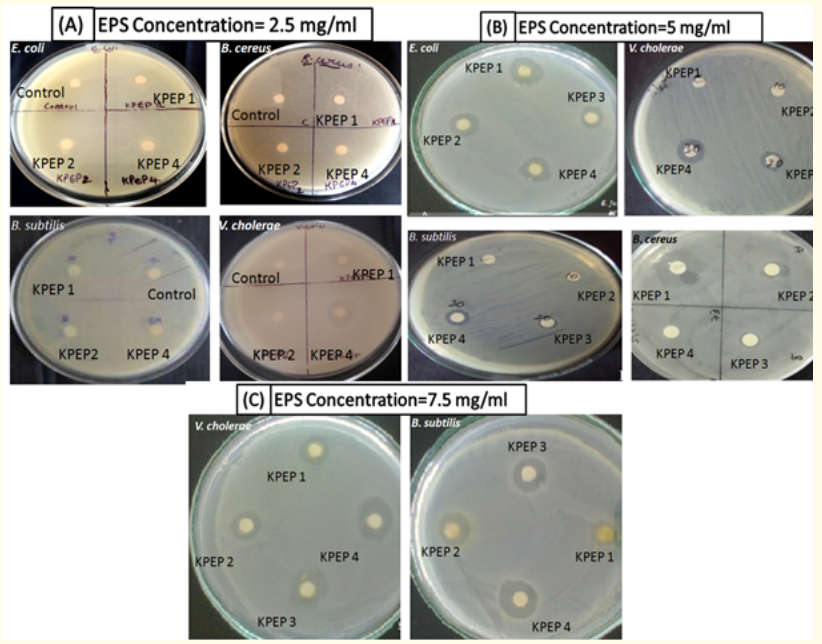

Figure 5: Antibacterial effects of extracted EPS on different test cultures: (A) The EPSs from all four isolates did not show significant antibacterial activity at concentration of 2.5 $\mathrm{mg} / \mathrm{ml}$. The distilled water soaked in paper disk was used as a negative control. (B) At $5 \mathrm{mg} / \mathrm{ml}$ EPS concentration all tested microorganisms showed sensitivity but KPEP1 showed higher antibacterial activity against Bacillus cereus with a larger zone of inhibition of $9 \mathrm{~mm}$. (C) At $7.5 \mathrm{mg} / \mathrm{ml}$ EPS concentration all four isolates' EPS were found to exert the higher antibacterial activity; however KPEP4-EPS showed larger zone of inhibition of 9 and $8 \mathrm{~mm}$ respectively against Bacillus subtilis and Vibrio cholerae followed by KPEP3-EPS.

\begin{tabular}{|c|c|c|}
\hline EPS $s$ & Test Bacterial Culture & MIC $(\mathbf{m g} / \mathbf{m l})$ \\
\hline KPEP1 & E. coli & 8.7 \\
\hline KPEP2 & Vibrio cholerae & 7.6 \\
\hline KPEP3 & Bacillus cereus & 9.4 \\
\hline KPEP4 & Bacillus subtilis & 6.8 \\
\hline
\end{tabular}

Table 3: MIC of different EPSs for test microorganisms.

Phenotypic and Biochemical characterization of the EPSproducing Bacteria

Isolated cultures were identified on the basis of morphological, biochemical and microscopic observations (Table 4). The identification work was done according to the methods described in Bergey's Manual of determinative bacteriology 9th edition. The Morphological and biochemical characteristics of all four isolates are shown in tables 4 and 5 respectively; which suggest that KPEP1, KPEP2 and KPEP3 belongs to Gram positive Bacillus spp. whereas KPEP4 belongs to Gram negative Pseudomonas spp. 


\begin{tabular}{|c|c|c|c|c|}
\hline Characteristics & KPEP1 & KPEP2 & KPEP3 & KPEP4 \\
\hline Size & Large & Small & Small & Medium \\
\hline Shape & Irregular & Circular & Round & Oval \\
\hline Margin & Entire & Entire & Entire & Undulate \\
\hline Elevation & Convex & Convex & Convex & Convex \\
\hline Texture & Mucoidal & Smooth & Mucoidal & Smooth \\
\hline Opacity & Translucent & Opaque & Opaque & Translucent \\
\hline Pigmentation & No & Yellow & No & Greenish \\
\hline Odour & No & No & No & No \\
\hline Consistency & Moist & Viscid & Moist & Moist \\
\hline Motility & Motile & Motile & Non-motile & Motile \\
\hline Gram's staining & Gram Positive rods & Gram Positive rods & Gram Positive large rods & Gram Negative Short rods \\
\hline
\end{tabular}

Table 4: Morphological Characterization of EPS producing isolates.

\begin{tabular}{|c|c|c|c|c|}
\hline Biochemical Test & KPEP1 & KPEP2 & КРЕР3 & KPEP4 \\
\hline Indole production test & - & - & + & - \\
\hline Methyl red test & - & + & - & - \\
\hline Voges Proskauer test & + & + & + & - \\
\hline Nitrate reduction test & + & - & + & + \\
\hline Citrate utilization test & - & + & + & + \\
\hline Triple Sugar Iron Test & + & + & + & + \\
\hline Lactose utilization test & - & + & - & - \\
\hline Dextrose utilization test & + & + & + & + \\
\hline Fructose utilization test & + & + & - & + \\
\hline Xylose utilization test & - & - & + & + \\
\hline Mannitol utilization test & - & - & - & + \\
\hline Oxidase test & + & + & - & + \\
\hline Catalase test & + & + & + & + \\
\hline Starch hydrolysis test & + & + & + & + \\
\hline Gelatin hydrolysis test & + & + & + & + \\
\hline Lipid hydrolysis test & - & + & - & + \\
\hline Casein hydrolysis test & + & + & + & + \\
\hline Urea hydrolysis test & - & - & + & + \\
\hline ONPG hydrolysis & - & - & + & - \\
\hline Arginine Dihydrolase Test & - & - & - & + \\
\hline $\begin{array}{l}\text { Predicted Genera of the EPS Producing } \\
\text { Isolates }\end{array}$ & Bacillus spp & Bacillus spp & Bacillus spp & Pseudomonas spp \\
\hline
\end{tabular}

Table 5: Biochemical Characterization of EPS producing isolates.

$(+)=$ Positive test; $(-)=$ Negative test. 
Although few microbial EPSs like xanthan, sphingans, cellulose etc. have gained commercial importance, more interest is being developed among researchers to explore novel bacterial EPS. The inherent biocompatibility and apparent non-toxic nature of some of these bacterial exopolysaccharides has prompted their uses in numerous medical applications such as antimicrobial, scaffolds or matrices in tissue engineering, drug delivery and wound dressing, thereby making them more attractive as compared to polysaccharides obtained from plants and microalgae. Some biopolymers are gradually degraded in vivo, making them well suited for use in tissue replacement and controlled drug release. However, only a few of the huge number of new bacterial EPSs reported over recent decades have emerged as industrially important biopolymers with significant commercial value, particularly with regard to their use as biomaterials $[13,14]$. Some bacterial EPSs such as xanthan gum or gellan gum can be used as an alternate to polysaccharides extracted from plants (e.g. guar gum or pectin) or algae (e.g. carrageenan or alginate) in traditional applications, because of their improved physical properties $[14,15]$. However, other bacterial EPSs such as bacterial cellulose or levan possess unique properties that may lead to development of new medicinal products [16,17]. In addition, bacteria offer wide diversity of exocellular substances with characteristic composition and properties that provide opportunities for the development of new medicinal product with improved properties such as antimicrobial activity. The present study thus conducted with the aim to isolate potent EPS producing bacteria from sugarcane field soil of Tarsadi, Gujarat region and to explore EPSs antibacterial activity. Four bacterial isolates namely, KPEP1 KPEP2, KPEP3 and KPEP4 were found to produce EPS efficiently at $\mathrm{pH}$ 6.0. The EPS from all the isolates were successfully extracted and carbohydrate and protein contents were measured. The maximum carbohydrate content was found in KPEP3-EPS and lower protein content was found in KPEP4-EPS, suggesting that it can be a good source for use in medical purposes since, due to higher immunogenicity of proteins; it is desirable to have less protein content in the microbial products.

Furthermore, the KPEP3 and KPEP4 isolates were found to produce higher EPS as compared to other two isolates, suggesting that they can be employed at pilot and industrial scale production of EPS. Albeit, all four EPSs showed good antibacterial activity, the KPEP3-EPS and KPEP4-EPS were found to possess higher antibacterial activity on the diverse test organisms as compared to other two isolates' EPS. This indicates of that these two isolates could be a good source of EPSs and its use in medical purpose. The EPS concentration of $7.5 \mathrm{mg} / \mathrm{ml}$ was found to be effective for antibacterial activity. In addition, The MIC values suggested that EPSs were effective at minimum concentrations to inhibit the growth of different test organisms; which is desirable to avoid any side effects of higher doses of medical drug. However, the efficacy studies, in vitro and in vivo studies are yet to be carried out for these EPSs to be proven as good alternative of other antibacterial drugs. Previously, antibacterial activity of EPSs of Lentinus subnudus was shown using Swiss Albino Rats as animal model, and proposing that the EPSs of L. subnudus as non-toxic substance of medicinal value [18]. Study by Li., et al. [19] reported that exopolysaccharides from Bifidobacterium bifidum WBIN03 and Lactobacillus plantarum R315 exhibited an- tibacterial activities against tested pathogens such as Cronobacter sakazakii, Escherichia coli, Listeria monocytogenes, Staphylococcus aureus, Candida albicans, Bacillus cereus, Salmonella typhimurium and Shigella sonnei at $300 \mu \mathrm{g} / \mathrm{mL}$. Onbasli and Aslim [20] suggested that $P$. aeruginosa can utilize molasses and produce effective EPS which showed potent antibacterial activity against Bacillus subtilis and Escherichia coli.

The identification of isolates is very necessary in order to get their full information of physiological aspects. The morphological and biochemical characterization suggested that the isolates belong to Bacillus spp and Pseudomonas spp mainly. However, molecular identification by 16SrRNA sequencing is yet to be done to confirm their identification at species level. The composition of EPS is very important when it would be used as drug or any other purposes where it is delivered in natural systems. The present study has done few preliminary analyses of carbohydrates present in the EPS, which suggested that EPS may contain arabinose and xylose, glucose, galactose and sucrose sugars. Previously, two newly reported bacterial EPSs with great potential include GalactoPol, synthesized by Pseudomonas oleovorans, which is composed mainly of galactose and FucoPol, a fucose-containing EPS that is synthesized by Enterobacter A47 [21,22].

The efficiency to produce EPS by bacterial strain is also crucial, if the EPS is to be produced at industrial scale due to its significant use. Our results were found comparable and better as compared to earlier report which suggested to recover bacterial EPS from basal medium was $90.66 \pm 16.8 \mathrm{mg} / 100 \mathrm{ml}$ of dry weight [23], whereas the present study recovered 259 and $312 \mathrm{mg} / 100 \mathrm{ml}$ of EPS from the isolates KPEP3 and KPEP4 respectively indicating the potent EPS producers have been isolated in the present study. Previously, Kaur., et al. [24] also isolated efficient EPS producing Alcaligenes Faecalis B14 from indigenous soil. One study by Pawar., et al. [25] reported the maximum EPS production of $5 \mathrm{gm} / \mathrm{l}$ by one isolate predicted as Alpha Proteobacterium group, obtained from saline soil, suggesting that different ecological environment may possess different diversity of such EPS-producing bacteria and their EPS producing capability may differ according to the type of bacteria and even the strains. In addition, the EPS production largely depends on the substrate composition and environmental conditions [26].

\section{Conclusion}

The results of the present study recommend that bacteria (KPEP1, KPEP2, KPEP3 and KPEP4) isolated from sugar cane field soil sample are found to be good EPS producers. In particular, the KPEP3 and KPEP4 were found as efficient EPS producers with the higher and diverse antibacterial activity of EPS as compared to other two isolates. In addition, MIC values of the EPSs suggested that they were effective in inhibiting the growth of test organisms at lower concentrations as well. The antimicrobial activities of EPSs could be used as a potential source for the development of antimicrobial drugs and may have various industrial, pharmaceutical and medical applications. However, further research is necessary to prove the above mentioned findings by EPS production at pilot scale, analyzing composition of EPS and efficacy of EPS by in 
vitro and in vivo animal studies.

\section{Acknowledgements}

We are thankful to Uka Tarsadia University, Bardoli, Gujarat, India for providing necessary research facilities to conduct the study.

\section{Conflict of Interest}

Authors declare no conflict of interest.

\section{Bibliography}

1. Staudt C., et al. "Volumetric measurements of bacterial cells and extracellular polymeric substance glycoconjugates in biofilms". Biotechnology and Bioengineering 88.5 (2004): 585592.

2. Knoshaug EP., et al. "Growth associated exopolysaccharide expression in Lactococcus lactis subspecies cremoris Ropy352". Journal of Dairy Science 83.4 (2000): 633-640.

3. Rehm BH. "Bacterial polymers: biosynthesis, modifications and applications". Nature Reviews Microbiology 8.8 (2010): 578-592.

4. Linton CM. "Radiation and diffraction of water waves by a submerged sphere in finite depth". Ocean Engineering 18.1-2 (1991): 61-74.

5. Sutherland IW. "Novel and established applications of microbial polysaccharides". Trends in Biotechnology 16.1 (1998): 41-46.

6. Flemming H C and Wingender J. "Relevance of microbial extracellular polymeric substances (EPSs)-Part I: Structural and ecological aspects". Water Science and Technology 43.6 (2001): $1-8$.

7. Vijayabaskar P., et al. "Quantification and characterization of exopolysaccharides from Bacillus subtilis (MTCC 121)". Advances in Biological Research 5.2 (2011): 71-76.

8. Gerhardt P., et al. "Methods for General and Molecular Bacteriology". Washington, DC: American Society for Microbiology (1994) 518.

9. Frølund B., et al. "Extraction of extracellular polymers from activated sludge using a cation exchange resin". Water Research 30.8 (1996): 1749-1758

10. Lowry 0.H., et al. "Protein measurement with the Folin phenol reagent". Journal of Biological Chemistry 193.1 (1951): 265725 .

11. Raihan S., et al. "Production of exopolysaccharide by an indigonous soil isolate". Journal Islamic Academy Sciences 5.4 (1992): 282-285.

12. Bauer A., et al. "Antibiotic Susceptibility Testing by a Standardized Single Disk Method". American Journal of Clinical Pathology 36.3 (1966): 493-496.

13. Chawla PR. "Microbial cellulose: fermentative production and applications". Food Technol Biotechnology 47.2 (2009): 107124.
14. Rehm HYU. "Microbial production of biopolymers and polymer precursors: applications and perspectives". Caister Academic Press (2009).

15. Fialho AM. "Occurrence, production, and applications of gellan: current state and perspectives". Applied Microbiology and Biotechnology 79.6 (2008): 889-900.

16. Kumar AS. "Bacterial exopolysaccharides -a perception". Journal of Basic Microbiology 47 (2007): 103-117.

17. Ullrich THJ. "Bacterial Polysaccharides: Current Innovations and Future Trends". Caister Academic Press (2009).

18. Majolagbe ON., et al. "Study on the Antibacterial Activity of Exopolysaccharides of Lentinus subnudus Using Swiss Albino Rats as Animal Model". American-Eurasian Journal of Scientific Research 8.1 (2013): 47-52.

19. Li S., et al. "Antioxidant and antibacterial activities of exopolysaccharides from Bifidobacterium bifidum WBIN03 and Lactobacillus plantarum R315". Journal of Dairy Science 97.12 (2014): 7334-7343.

20. Onbasli D and Aslim B. "Determination of antimicrobial activity and production of some metabolites by Pseudomonas aeruginosa B1 and B2 in sugar beet molasses". African Journal of Biotechnology 7.24 (2008): 4614-4619.

21. Freitas F., et al. "Characterization of an extracellular polysaccharide produced by a Pseudomonas strain grown on glycerol". Bioresource Technology 100.2 (2009): 859-865.

22. Freitas F., et al. "Fucose-containing exopolysaccharide produced by the newly isolated Enterobacter strain A47 DSM 23139”. Carbohydrate Polymers 83.1 (2011): 159-165.

23. Shankar T., et al. "Screening of Exopolysaccharide Producing Bacterium Frateuria Aurentia From Elephant Dung". Applied Science Reports 1.3 (2014): 105-109.

24. Kaur V., et al. "Production and Characterization of Exopolysaccharide Produced by Alcaligenes Faecalis B14 Isolated from Indigenous Soil”. International Journal of Biotechnology and Bioengineering Research 4.4 (2013): 365-374.

25. Pawar ST., et al. "Isolation, screening and optimization of exopolysaccharide producing bacterium from saline soil". Journal of Microbiology and Biotechnology Research 3.3 (2013): 24-31.

26. Rabha B., et al. "Effect of some fermentation substrates and growth temperature on exopolysaccharide production by Streptococcus thermophilus BN1". International Journal of Bioscience, Biochemistry and Bioinformatics 2.1 (2012): 4447.

\section{Volume 1 Issue 4 April 2018}

(C) All rights are reserved by Mitesh Dwivedi., et al. 